\title{
Electrocatalytic Oxidation of Methanol on Glassy Carbon Electrode Modified by Metal Ions (Copper and Nickel) Dispersed into Polyaniline Film
}

\author{
Asmea Khouchaf*, Driss Takky, Mohammed El Mahi Chbihi, Said Benmokhtar \\ Department of Chemistry, Faculty of Sciences, Laboratory of Chemistry and Physics of Materials LCPM, \\ University of Casablanca, Casablanca, Morocco \\ Email: "asmea.khouchaf@gmail.com
}

Received 24 October 2015; accepted 21 February 2016; published 25 February 2016

Copyright (C) 2016 by authors and Scientific Research Publishing Inc.

This work is licensed under the Creative Commons Attribution International License (CC BY).

http://creativecommons.org/licenses/by/4.0/

(c) ()) Open Access

\begin{abstract}
Polyaniline film was prepared by using the repeated potential cycling technique in an acidic solution at the surface of glassy carbon electrode. Then transition metal ions of $\mathrm{Ni}$ and $\mathrm{Cu}$ were incorporated to the polymer by immersion of the modified electrode. A comparative study of the electrocatalytic oxidation of methanol is made in $\mathrm{NaOH}$, on $\mathrm{Ni}$ and $\mathrm{Cu}$ on polyaniline film covered glassy carbon electrode (Ni-PANI-GC, Cu-PANI-GC) at $25^{\circ} \mathrm{C}$. Catalytic activity for the oxidation of methanol was studied by using cyclic voltammetry.
\end{abstract}

Keywords

Methanol, Polyanilne, Cyclic Voltammetry, Electrocatalytic Oxidation

\section{Introduction}

Direct methanol fuel cells (DMFC) are the promising power sources for applications such as electric vehicles and electronic portable. Methanol as a fuel has numerous advantages such as low operating temperature, easy transportation and fuel storage, high-energy efficiency, low exhaustion and fast start-up [1] [2].

The electrooxidation of methanol on platinum and a variety of other metals has been the subject of numerous studies. In order to improve the activity of methanol electrooxidation, types of mono-metallic electrodes [3]-[8], bimetallic [9]-[17] or multimetallic [18]-[25] are directly used to oxidize methanol. Besides, these electrodes are

${ }^{*}$ Corresponding author.

How to cite this paper: Khouchaf, A., Takky, D., Chbihi, M.El.M. and Benmokhtar, S. (2016) Electrocatalytic Oxidation of Methanol on Glassy Carbon Electrode Modified by Metal Ions (Copper and Nickel) Dispersed into Polyaniline Film. Journal of Materials Science and Chemical Engineering, 4, 97-105. http://dx.doi.org/10.4236/msce.2016.42011 
first incorporated in the aniline polymer before using. Moreover the synergy effect of different electrodes was scrutinized [26]-[31].

Conductive polymers are important materials because of their specific properties, simple preparation and possible application to electrochemical energy conversion. The conducting polymers used are mainly polyaniline [32]-[41] poly(2-Methoxyaniline)-sodium dodecyl sulfatecomposite [42], poly(2-aminodiphenylamine) [43], poly(vinylferrocene) [44], poly(1,5-diaminonaphthalene) [45], polyindoles [46] and poly(o-aminophenol) [47] [48]. Polymers are usually used as matrix to incorporate noble metal [49] [50] and no noble metal [34] [43] [45] catalysts in the electrooxidation of methanol. Polyaniline (PANI) is one of the best candidates because it can easily be prepared on the electrode substrate as a homogeneous and strong adherent film with a high surface area and good stability in acid media.

In the present work, in order to investigate the effect of PANI nanofibers in methanol electrooxidation reaction, two types of anode, $\mathrm{Ni}$ and $\mathrm{Cu}$, were prepared and investigated by cyclic voltammetry.

\section{Experimental}

Electrochemical experiments were carried out with a voltalab potentiostat (model PGZ 100) by the general purpose electrochemical systems data processing software (Voltamaste 4). All electrochemical measurements were conducted in a three-compartment electrochemical cell with platinum as the counter electrode; a silver/silver chloride reference $(\mathrm{Ag} / \mathrm{AgCl} / \mathrm{KCl})$ as the reference electrode, and carbon glassy electrode was used as the working electrode.

The solutions were prepared using Double-distilled water, super pure $\mathrm{NaOH}, \mathrm{H}_{2} \mathrm{SO}_{4}, \mathrm{CuSO}_{4}, 5 \mathrm{H}_{2} \mathrm{O}, \mathrm{NiSO}_{4}, 6$ $\mathrm{H}_{2} \mathrm{O}$ and $\mathrm{C}_{6} \mathrm{H}_{5} \mathrm{NH}_{2}$ of analytical grade. $(\mathrm{Ag} / \mathrm{AgCl} / \mathrm{KCl})$ electrode was served as reference electrode. Potentials in this paper were reported versus the $(\mathrm{Ag} / \mathrm{AgCl} / \mathrm{KCl})$ scale. The solution was deaerated by bubbling pure $\mathrm{N}_{2}$ gas before experiment, and kept a flux of $\mathrm{N}_{2}$ over it during measurements to prevent possible interference of oxygen and impurities from the atmosphere. All tests were performed at $25^{\circ} \mathrm{C}$.

\section{Results and Discussion}

\subsection{Preparation of PANI/CG Electrode}

Previously polyaniline films were obtained at the surface of $\mathrm{Au}, \mathrm{Pt}$, and $\mathrm{CP}$ electrodes [51]-[53]. In this work, electropolymerization at the surface of GC using consecutive cyclic voltammetry (for 15 cycles) between -0.2 and $1.2 \mathrm{~V}$ at $50 \mathrm{mVs}^{-1}$ was performed in sulfuric acid solution $0.5 \mathrm{M}$ containing $0.1 \mathrm{M} \mathrm{C}_{6} \mathrm{H}_{5} \mathrm{NH}_{2}$ (Figure 1). As can be seen, the electrooxidation of aniline starts at $0.97 \mathrm{~V}$ in the first cycle and produces the first layer of po-

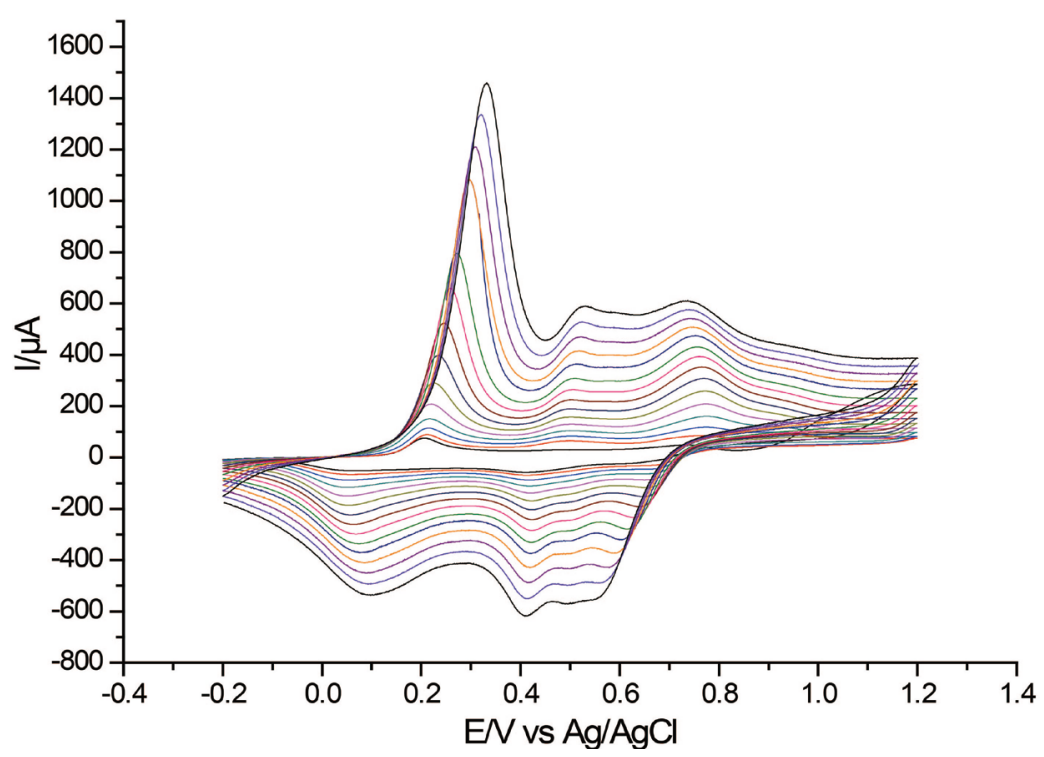

Figure 1. Series of $\mathrm{CV}$ during 15 potential cycles between -0.2 and $1.2 \mathrm{~V}$ in a $0.5 \mathrm{M} \mathrm{H}_{2} \mathrm{SO}_{4}$ solution containing $0.1 \mathrm{M}$ Aniline at a glassy carbon electrode, scan rate $50 \mathrm{mVs}^{-1}$. 
lyaniline. Subsequent cycles indicate a successive growth of the polyaniline film as evidenced by the increase in the redox current. Two redox couples are readily apparent with $\mathrm{E}$ values of 0.20 and $0.76 \mathrm{~V}$ in the CV.

\subsection{Preparation of $\mathrm{Cu}-\mathrm{PANI}-\mathrm{GC}$}

The electrodeposition of $\mathrm{Cu}$ was performed in a solution of $0.25 \mathrm{M} \mathrm{CuSO}_{4}+0.1 \mathrm{M} \mathrm{H}_{2} \mathrm{SO}_{4}$, and the applied potential and time were optimized as $-0.175 \mathrm{~V}$ and $30 \mathrm{~min}$, respectively.

Figure 2(A) shows cyclic voltammograms of Cu/PANI/CGE in $0.1 \mathrm{M} \mathrm{NaOH}$ solution at a scan rate of 10 $\mathrm{mVs}^{-1}$. The voltammogram is in good agreement with those reported in literature [26] [31]-[34] [36], some redox transitions appeared and were indicated by I-III. From the cyclic voltammogram depicted in this figure and the literature [54]-[56], peak a at less than $-0.5 \mathrm{~V}$ vs. Ag/AgCl may be attributed to the electrosorption of oxygen, peak $b$ is attributed to the $\mathrm{Cu} / \mathrm{Cu}(\mathrm{I})$ redox couple, peak c attributed to the $\mathrm{Cu} / \mathrm{Cu}(\mathrm{II})$ as well as $\mathrm{Cu}(\mathrm{I}) / \mathrm{Cu}(\mathrm{II})$, Peak d to $\mathrm{Cu} / \mathrm{CuII}$ (soluble species), peak e is associated with the formation of $\mathrm{Cu}(\mathrm{III})$ species, It has been proposed that $\mathrm{Cu}(\mathrm{III})$ species are more easily formed, and indeed detected, at high hydroxide concentration. In our case, the oxidative wave for the formation $\mathrm{Cu}$ (III) species may be under the rising portion of the current at about $0.57 \mathrm{~V}$. and peaks $\mathrm{f}$, g and $\mathrm{h}$ the cathodic half cycle are assigned to the reduction of $\mathrm{Cu}(\mathrm{I})$ to $\mathrm{Cu}, \mathrm{Cu}(\mathrm{II})$ to $\mathrm{Cu}(\mathrm{I})$ and $\mathrm{Cu}(\mathrm{III})$ to $\mathrm{Cu}(\mathrm{II})$ respectively.

In the presence of $0.5 \mathrm{~mol} \cdot \mathrm{l}^{-1}$ methanol Figure 2(B), there is augmentation of currents at potentials corresponding to redox reactions involving low oxidation states of $\mathrm{Cu}$ (peaks c, d) and peak e was replaced by a remarkably high anodic peak resulting from oxidation of methanol. The onset potential of the electrocatalytic oxidation appeared at $0.57 \mathrm{~V}$ vs $\mathrm{Ag} / \mathrm{AgCl}$.

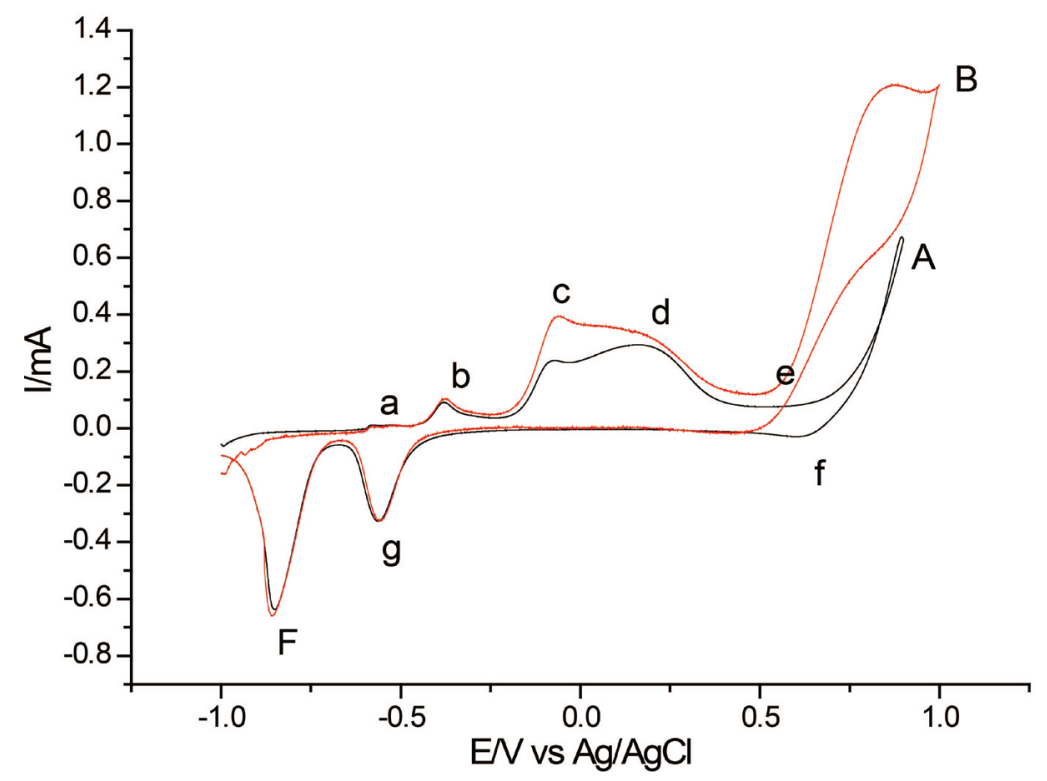

Figure 2. Typical cyclic voltammogram of Cu-PANI-CGE in $0.1 \mathrm{M} \mathrm{NaOH}$ solution in the absence (A) and presence (B) of $0.5 \mathrm{M}$ methanol, scan rate $10 \mathrm{mVs}^{-1}$.

\subsection{Effect of Methanol Concentration}

Figure 3 shows the behavior of this modified electrode in the presence of different methanol concentrations of $0.1 \mathrm{M} \mathrm{NaOH}$ at the scan rate of $10 \mathrm{mV} \cdot \mathrm{s}^{-1}$, respectively. It is clearly observed that upon increasing methanol concentration its oxidation develops in the region of the electrochemical formation of $\mathrm{Cu}(\mathrm{III})$. Thus, it is likely that the $\mathrm{Cu}(\mathrm{III})$ species is the active moiety which efficiently speeds up the oxidation of methanol. The oxidation current density increases with increasing methanol concentration and levels off at concentrations higher than $0.5 \mathrm{M}$.

\subsection{Preparation of Ni- PANI-GC}

In order to prepare the Ni-PANI composite, a freshly electropolymerized CGE was placed at open circuit in an 

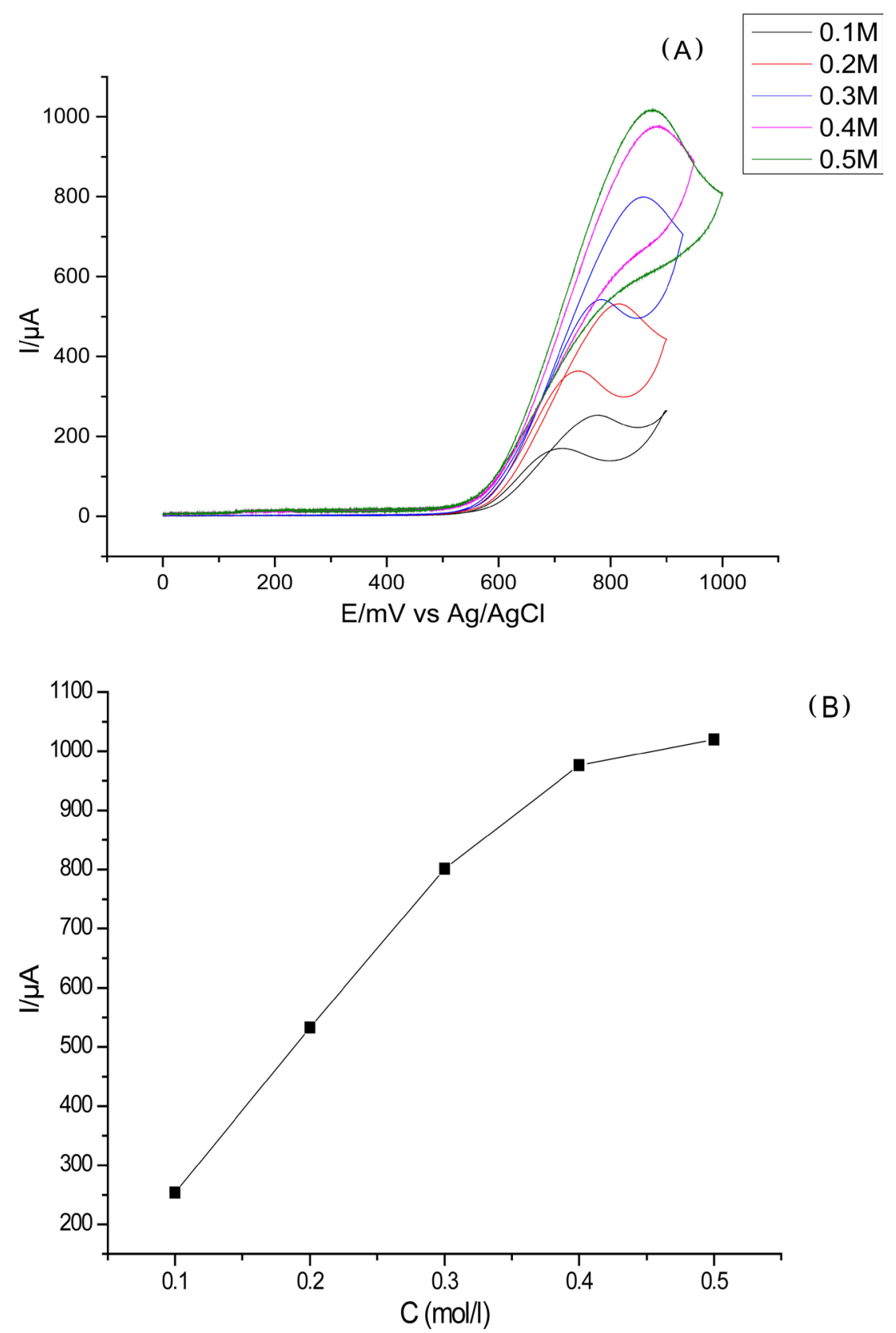

(B)

Figure 3. (A) Current-potential curves of $0.1 \mathrm{M} \mathrm{NaOH}$ solution with different concentrations of methanol $0.1-0.5 \mathrm{M}$ at the $\mathrm{Cu}-\mathrm{PANI}-\mathrm{GC}$ at scan rate of $10 \mathrm{mVs}^{-1}$. (B) Plot of the dependence of methanol oxidation peak current on the methanol concentration.

aqueous $0.1 \mathrm{M} \mathrm{H}_{2} \mathrm{SO}_{4}$ solution of $0.2 \mathrm{M} \mathrm{NiSO}_{4}$. The accumulation of nickel was conducted by complex formation between $\mathrm{Ni}(\mathrm{II})$ and amine sites in the polymer backbone. After incorporating $\mathrm{Ni}$ ion into the polymer using the procedure discussed above, the polarization behavior was examined in $0.1 \mathrm{M} \mathrm{NaOH}$ for Ni/PANI/CGE using cyclic voltammetry. Voltammograms were recorded by cycling the potential between 0 and $0.7 \mathrm{~V}$ at $10 \mathrm{mVs}^{-1}$ until a stable voltammogram was obtained. Figure 4(A), from this figure it can be seen that a well redox pair was observed on the Ni-PANI-CGE when the potential was cycled between 0.0 and $0.7 \mathrm{~V}$, which was related to the oxidation of $\mathrm{Ni}(\mathrm{II})$ to $\mathrm{Ni}$ (III) with a peak potential of $0.46 \mathrm{~V}$ and reduction of $\mathrm{Ni}(\mathrm{III})$ to $\mathrm{Ni}$ (II) with a peak potential of $0.38 \mathrm{~V}$. Our results show that methanol can be effectively catalyzed on the surface of Ni-PANI-CGE Figure 4(B). 


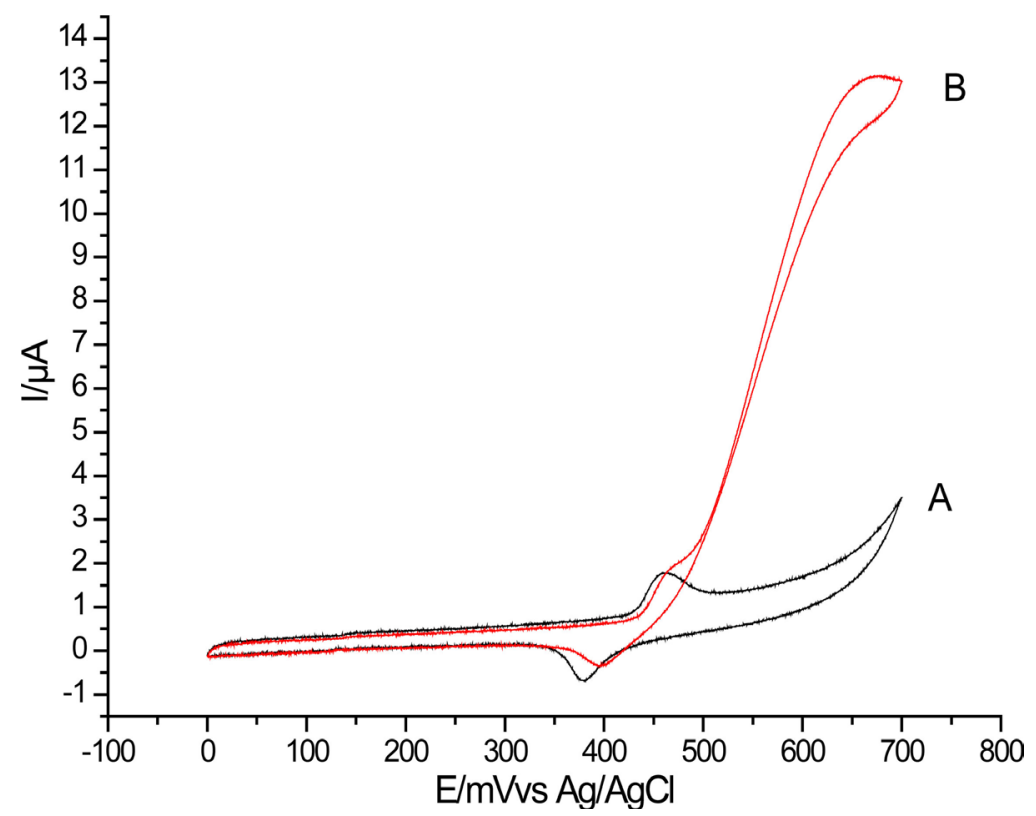

Figure 4. Electrochemical responses of Ni-PANI-GC in $0.1 \mathrm{M} \mathrm{NaOH}$ solution with scan rate of $10 \mathrm{mVs}^{-1}$ to: (A) $0.0 \mathrm{M}$, (B) $0.1 \mathrm{M}$ methanol.

\subsection{Effect of Methanol Concentration}

Figure 5(A) presents the effect of various methanol concentrations on the electrooxidation current at the NiPANI-GCE. As shown in this figure, when the excessive concentrations are added, the oxidation peak currents increase. The anodic current in the positive sweep was proportional to the concentration of methanol, and any increase in the concentration of methanol caused an almost proportional linear enhancement of the anodic current Figure 5(B). Moreover, in the presence of methanol, the onset potential of the Ni(II) moiety oxidation shifted to a positive value and enhanced upon increasing the concentration of methanol. In fact, this indicated a strong interaction of methanol with the surface already covered by nickel species. This indicates that methanol is oxidized by active nickel. The electrocatalytic oxidation of methanol occurs not only in the anodic but also continues in the initial stage of the cathodic half cycle.

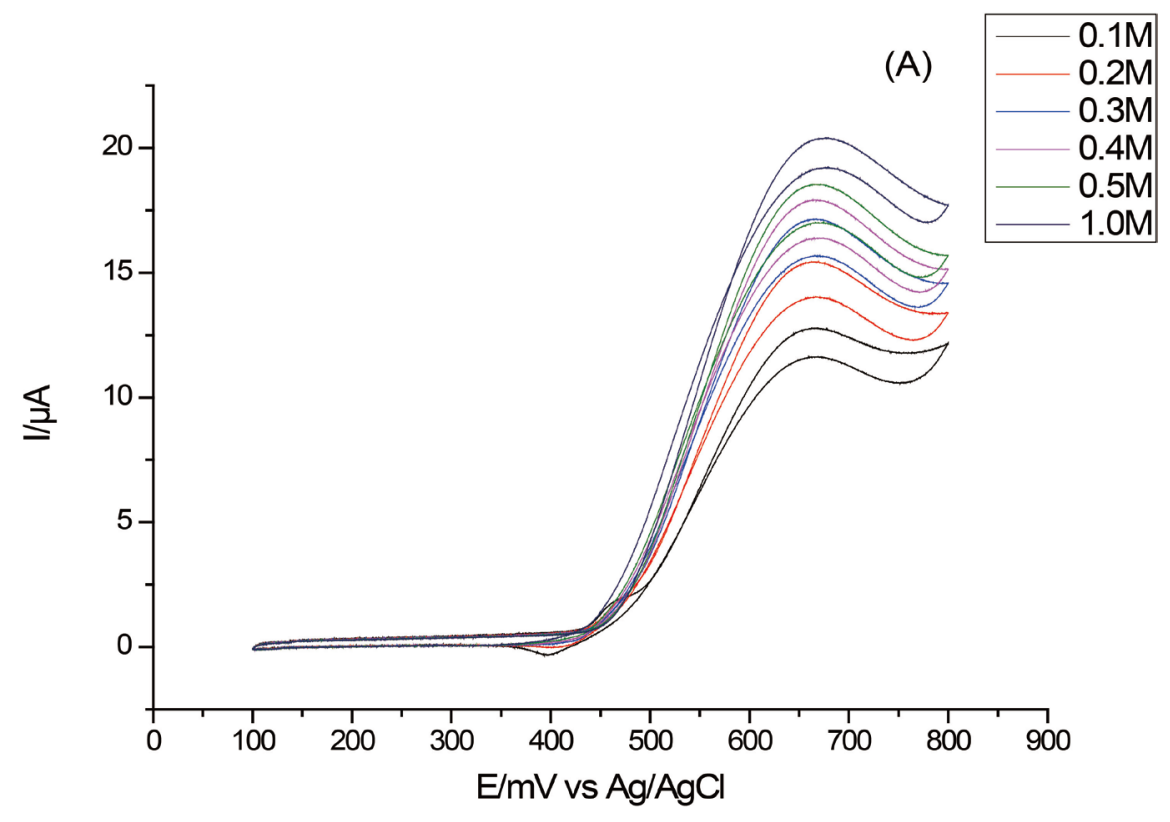




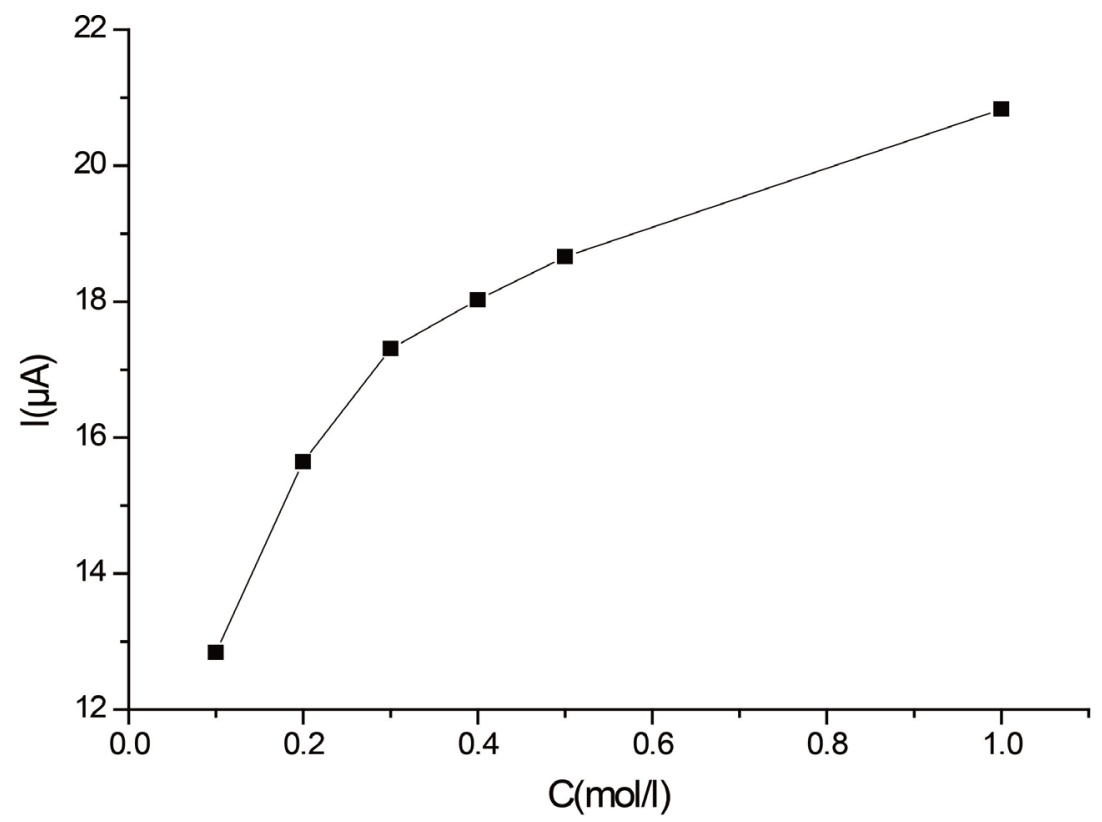

(B)

Figure 5. (A) Current-potential curves of the Ni-PANI-CGE for electrocatalytic oxidation of methanol at the scan rate of 10 $\mathrm{mVs}^{-1}$ in $0.1 \mathrm{M} \mathrm{NaOH}$ solution with different concentrations of methanol: $0.1-1 \mathrm{M}$, respectively. Inset (B) represents the dependence of methanol oxidation peak current on the methanol concentration.

\section{Conclusion}

In this work, we have shown the advantageous features of carbon glassy technology, polymer modification and dispersion of metallic particles into an organic polymer. The experimental results described show that glassy carbon electrodes which are modified with $\mathrm{Ni}$ and $\mathrm{Cu}$ on polyaniline film are useful for the electrooxidation of methanol in alkaline medium using CV method. The response for methanol electro-oxidation at the Cu-PANIGC electrode is significantly larger than the response obtained for Ni-PANI-GC electrode.

\section{References}

[1] Andujar, J.M. and Segura, F. (2009) Fuel Cells: History and Updating. A Walk along Two Centuries. Renewable and Sustainable Energy Reviews, 13, 2309-2322. http://dx.doi.org/10.1016/j.rser.2009.03.015

[2] Kamarudin, S.K., Achmad, F. and Daud, W.R.W. (2009) Overview on the Application of Direct Methanol Fuel Cell (DMFC) for Portable Electronic Devices. International Journal of Hydrogen Energy, 34, 6902-6916. http://dx.doi.org/10.1016/j.ijhydene.2009.06.013

[3] Han, S.B., Song, Y.J., Lee, J.M., Kim, J.Y. and Park, K.W. (2008) Platinum Nanocube Catalysts for Methanol and Ethanol Electrooxidation. Electrochemistry Communications, 10, 1044-1047. http://dx.doi.org/10.1016/j.elecom.2008.04.034

[4] Xu, C.W., Hu, Y.H., Rong, J.H., Jiang, S.P. and Liu, Y.L. (2007) Ni Hollow Spheres as Catalysts for Methanol and Ethanol Electrooxidation. Electrochemistry Communications, 9, 2009-2012. http://dx.doi.org/10.1016/j.elecom.2007.05.028

[5] Guo, Y., Xu, Y.T., Gao, G.H., Wang, T., Zhao, B., Fu, X.Z., Sun, R. and Wong, C.P. (2015) Electro-Oxidation of Formaldehyde and Methanol over Hollow Porous Palladium Nanoparticles with Enhanced Catalytic Activity. Catalysis Communications, 58, 40-45.

[6] Heli, H., Jafarian, M., Mahjani, M.G. and Gobal, F. (2004) Electro-Oxidation of Methanol on Copper in Alkaline Solution. Electrochimica Acta, 49, 4999-5006. http://dx.doi.org/10.1016/j.electacta.2004.06.015

[7] Borkowska, Z., Tymosiak-Zielinska, A. and Shul, G. (2004) Electrooxidation of Methanol on Polycrystalline and Single Crystal Gold Electrodes. Electrochimica Acta, 49, 1209-1220. http://dx.doi.org/10.1016/j.electacta.2003.09.046

[8] Orozco, G., Pérez, M.C., Rincón, A. and Gutiérrez, C. (2000) Electrooxidation of Methanol on Silver in Alkaline Medium. Journal of Electroanalytical Chemistry, 495, 71-78. http://dx.doi.org/10.1016/s0022-0728(00)00396-x

[9] Garbarino, S., Ponrouch, A., Pronovost, S. and Guay, D. (2009) Enhanced Stability and Activity of PtRu Nanotubes for 
Methanol Electrooxidation. Electrochemistry Communications, 11, 1449-1452. http://dx.doi.org/10.1016/j.elecom.2009.05.028

[10] Habibi, B. and Dadashpour, E. (2013) Carbon-Ceramic Supported Bimetallic Pt-Ni Nanoparticles as an Electrocatalyst for Electrooxidation of Methanol and Ethanol in Acidic Media. International Journal of Hydrogen Energy, 38, 5425-5434. http://dx.doi.org/10.1016/j.ijhydene.2012.06.045

[11] Yan, S. and Zhang, S. (2012) Methanol Electrooxidation on Carbon Supported Au Core-Pt Shell Nanoparticles Synthesized by an Epitaxial Growth Method. International Journal of Hydrogen Energy, 37, 9636-9644. http://dx.doi.org/10.1016/j.ijhydene.2012.03.058

[12] Long, N.V., Hien, T.D., Asaka, T., Ohtaki, M. and Nogami, M. (2011) Synthesis and Characterization of Pt-Pd Alloy and Core-Shell Bimetallic Nanoparticles for Direct Methanol Fuel Cells (DMFCs): Enhanced Electrocatalytic Properties of Well-Shaped Core-Shell Morphologies and Nanostructures. International Journal of Hydrogen Energy, 36 , 8478-8491. http://dx.doi.org/10.1016/j.ijhydene.2011.03.140

[13] Kim, J.H., Choi, S.M., Nam, S.H., Seo, M.H., Choi, S.H. and Kim, W.B. (2008) Influence of Sn Content on PtSn/C Catalysts for Electrooxidation of $\mathrm{C}_{1}-\mathrm{C}_{3}$ Alcohols: Synthesis, Characterization, and Electrocatalytic Activity. Applied Catalysis B: Environmental, 82, 89-102. http://dx.doi.org/10.1016/j.apcatb.2008.01.011

[14] Amin, R.S., El-Khatib, K.M., Hameed, R.M.A., Souaya, E.R. and Etman, M.A. (2011) Synthesis of Pt-Co Nanoparticles on Multi-Walled Carbon Nanotubes for Methanol Oxidation in $\mathrm{H}_{2} \mathrm{SO}_{4}$ Solution. Applied Catalysis A: General, 407, 195-203. http://dx.doi.org/10.1016/j.apcata.2011.08.045

[15] Asgari, M., Maragheh, M.G., Davarkhah, R., Lohrasbi, E. and Golikand, A.N. (2012) Electrocatalytic Oxidation of Methanol on the Nickel-Cobalt Modified Glassy Carbon Electrode in Alkaline Medium. Electrochimica Acta, 59, $284-$ 289. http://dx.doi.org/10.1016/j.electacta.2011.10.091

[16] Wang, Y., Zhang, D., Peng, W., Liu, L. and Li, M. (2011) Electrocatalytic Oxidation of Methanol at Ni-Al Layered Double Hydroxide Film Modified Electrode in Alkaline Medium. Electrochimica Acta, 56, 5754-5758. http://dx.doi.org/10.1016/j.electacta.2011.04.049

[17] Tarrus, X., Montiel, M., Valles, E. and Gomez, E. (2014) Electrocatalytic Oxidation of Methanol on CoNi Electrodeposited Materials. International Journal of Hydrogen Energy, 39, 6705-6713. http://dx.doi.org/10.1016/j.ijhydene.2014.02.057

[18] Wu, Y.N., Liao, S.J., Guo, H.F. and Hao, X.Y. (2013) High-Performance Pd@ PtRu/C Catalyst for the Anodic Oxidation of Methanol Prepared by Decorating Pd/C with a PtRu Shell. Journal of Power Sources, 224, 66-71. http://dx.doi.org/10.1016/j.jpowsour.2012.09.079

[19] Chen, M., Wang, Z.B., Ding, Y. and Yin, G.P. (2008) Investigation of the Pt-Ni-Pb/C Ternary Alloy Catalysts for Methanol Electrooxidation. Electrochemistry Communications, 10, 443-446. http://dx.doi.org/10.1016/j.elecom.2008.01.012

[20] Motlagh, M.K., Noroozifar, M. and Kakhki, M.S.E. (2011) Investigation of the Nanometals (Ni and Sn) in Platinum Binary and Ternary Electrocatalysts for Methanol Electrooxidation. International Journal of Hydrogen Energy, 36, 11554-11563. http://dx.doi.org/10.1016/j.ijhydene.2011.06.071

[21] Teran, F.E., Santos, D.M., Ribeiro, J. and Kokoh, K.B. (2012) Activity of PtSnRh/C Nanoparticles for the Electrooxidation of $\mathrm{C}_{1}$ and $\mathrm{C}_{2}$ Alcohols. Thin Solid Films, 520, 5846-5850. http://dx.doi.org/10.1016/j.tsf.2012.05.022

[22] Huerta, M.V.M., Rojas, S., de la Fuente, J.L.G., Terreros, P., Pena, M.A. and Fierro, J.L.G. (2006) Effect of Ni Addition over PtRu/C Based Electrocatalysts for Fuel Cell Applications. Applied Catalysis B: Environmental, 69, 75-84. http://dx.doi.org/10.1016/j.apcatb.2006.05.020

[23] Teliz, E., Diaz, V., Perez, I., Corengia, M. and Zinola, C.F. (2012) Carbon Supported Pt, Ru and Mo Catalysts for Methanol Electrooxidation. International Journal of Hydrogen Energy, 37, 14761-14768. http://dx.doi.org/10.1016/j.ijhydene.2011.12.084

[24] Telli, E., Döner, A. and Kardas, G. (2013) Electrocatalytic Oxidation of Methanol on Ru Deposited NiZn Catalyst at Graphite in Alkaline Medium. Electrochimica Acta, 107, 216-224. http://dx.doi.org/10.1016/j.electacta.2013.05.113

[25] Abdel Hameed, R.M. and El-Khatib, K.M. (2010) Ni-P and Ni-Cu-P Modified Carbon Catalysts for Methanol ElectroOxidation in KOH Solution. International Journal of Hydrogen Energy, 35, 2517-2529. http://dx.doi.org/10.1016/j.ijhydene.2009.12.145

[26] Luna, A.M.C. (2000) A Novel Electrocatalytic Polyaniline Electrode for Methanol Oxidation: Au, Pt/PANI. Journal of Applied Electrochemistry, 30, 1137-1142.

[27] Prasad, A.M., Santhosh, C. and Grace, A.N. (2012) Carbon Nanotubes and Polyaniline Supported Pt Nanoparticles for Methanol Oxidation towards DMFC Applications Pt /PANI. Applied Nanoscience, 2, 457-466.

[28] Yano, J., Shiraga, T. and Kitani, A. (2008) Dispersed Platinum and Tin Polyaniline Film Electrodes for the Anodes of the Direct Methanol Fuel Cell Sn Pt/PANI. Solid-State Electronics, 12, 1179-1182. 
http://dx.doi.org/10.1007/s10008-007-0469-z

[29] Kuo, C.W., Chen, S.J., Chen, P.R., Wub, T.Y., Tsai, W.T. and Tseng, C.G. (2013) Doping Process Effect of Polyaniline Doped with Poly(styrenesulfonic acid) Supported Platinum for Methanol Oxidation. Journal of the Taiwan Institute of Chemical Engineers, 44, 497-504. http://dx.doi.org/10.1016/j.jtice.2012.11.017

[30] Gharibi, H., Kakaei, K., Zhiani, M. and Taghiabadi, M.M. (2011) Effect of Polyaniline-Doped Trifluoromethane Sulfonic Acid Nanofiber Composite Film Thickness on Electrode for Methanol Oxidation Pt/PANI. International Journal of Hydrogen Energy, 36, 13301-13309. http://dx.doi.org/10.1016/j.ijhydene.2010.09.080

[31] Podlovchenko, B.I., Maksimov, Y.M., Gladysheva, T.D. and Kolyadko, E.A. (2000) Electrocatalytic Activity of Platinum-Polyaniline and Palladium-Polyaniline Systems Obtained by Cycling the Electrode Potential. Russian Journal of Electrochemistry, 36, 731-735. http://dx.doi.org/10.1007/BF02757672

[32] Niu, L., Li, Q., Wei, F., Wu, S., Liu, P. and Cao, X. (2005) Electrocatalytic Behavior of Pt-Modified Polyaniline Electrode for Methanol Oxidation: Effect of Pt Deposition Modes. Journal of Electroanalytical Chemistry, 578, 331-337. http://dx.doi.org/10.1016/j.jelechem.2005.01.014

[33] Nagashree, K.L. and Ahmed, M.F. (2009) Electrocatalytic Oxidation of Methanol on Cu Modified Polyaniline Electrode in Alkaline Medium. Journal of Applied Electrochemistry, 39, 403-410. http://dx.doi.org/10.1007/s10800-008-9685-1

[34] Nagashree, K.L. and Ahmed, M.F. (2010) Electrocatalytic Oxidation of Methanol on Ni Modified Polyaniline Electrode in Alkaline Medium. Solid-State Electronics, 14, 2307-2320. http://dx.doi.org/10.1007/s10008-010-1063-3

[35] Nagashree, K.L. and Ahmed, M.F. (2008) Electrocatalytic Oxidation of Methanol on Pt Modified Polyaniline in Alkaline Medium. Synthetic Metals, 158, 610-616. http://dx.doi.org/10.1016/j.synthmet.2008.04.006

[36] Niu, L., Li, Q., Wei, F., Chen, X. and Wang, H. (2003) Electrochemical Impedance and Morphological Characterization of Platinum-Modified Polyaniline Film Electrodes and Their Electrocatalytic Activity for Methanol Oxidation. Journal of Electroanalytical Chemistry, 544, 121-128.

[37] Ficicioglua, F. and Kadirgan, F. (1997) Electrooxidation of Methanol on Platinum Doped Polyaniline Electrodes: Deposition Potential and Temperature Effect. Journal of Electroanalytical Chemistry, 430, 179-182.

[38] Niu, L., Li, Q., Wei, F., Chen, X. and Wang, H. (2003) Formation Optimization of Platinum-Modified Polyaniline Films for the Electrocatalytic Oxidation of Methanol. Synthetic Metals, 139, 271-276. http://dx.doi.org/10.1016/S0379-6779(03)00170-X

[39] Zhiani, M., Rezaei, B. and Jalili, J. (2010) Methanol Electro-Oxidation on Pt/C Modified by Polyaniline Nanofibers for DMFC Applications. International Journal of Hydrogen Energy, 35, 9298-9305. http://dx.doi.org/10.1016/j.ijhydene.2010.03.050

[40] Wu, G., Li, L., Li, J.-H. and Xu, B.-Q. (2005) Polyaniline-Carbon Composite Films as Supports of Pt and PtRu Particles for Methanol Electrooxidation. Carbon, 43, 2579-2587.

[41] Yan, R. and Jin, B. (2014) Preparation and Electrochemical Performance of Polyaniline/Pt Microelectrodes. Electrochimica Acta, 115, 449-453. http://dx.doi.org/10.1016/j.electacta.2013.10.201

[42] Raoof, J.B., Hosseini, S.R. and Rezaee, S. (2014) Preparation of Pt/Poly(2-Methoxyaniline)-Sodium Dodecyl Sulfate Composite and Its Application for Electrocatalytic Oxidation of Methanol and Formaldehyde. Electrochimica Acta, 141, 340-348. http://dx.doi.org/10.1016/j.electacta.2014.07.054

[43] Ojani, R., Raoof, J.B. and Khanghah, Y.A. (2011) Copper-Poly(2-aminodiphenylamine) as a Novel and Low Cost Electrocatalyst for Electrocatalytic Oxidation of Methanol in Alkaline Solution. Electrochimica Acta, 56, 3380-3386. http://dx.doi.org/10.1016/j.electacta.2010.12.082

[44] Akgul, E., Gulce, A. and Gulce, H. (2012) Electrocatalytic Oxidation of Methanol on Poly(vinylferrocene) Modified Pt Electrode. Journal of Electroanalytical Chemistry, 668, 73-82.

[45] Ojani, R., Raoof, J.B. and Zavvarmahalleh, S.R.H. (2008) Electrocatalytic Oxidation of Methanol on Carbon Paste Electrode Modified by Nickel Ions Dispersed into Poly(1,5-diaminonaphthalene) Film. Electrochimica Acta, 53, 24022407. http://dx.doi.org/10.1016/j.electacta.2007.10.004

[46] Zhou, W., Du, Y., Ren, F., Wang, C., Xu, J. and Yang, P. (2010) High Efficient Electrocatalytic Oxidation of Methanol on Pt/Polyindoles Composite Catalysts. International Journal of Hydrogen Energy, 35, 3270-3279. http://dx.doi.org/10.1016/j.ijhydene.2010.01.083

[47] Habibi, B., Pournaghi-Azar, M.H., Abdolmohammad-Zadeh, H. and Razmi, H. (2009) Electrocatalytic Oxidation of Methanol on Mono and Bimetallic Composite Films: Pt and Pt-M (M=Ru, Ir and Sn) Nanoparticles in Poly(o-aminophenol). International Journal of Hydrogen Energy, 34, 2880-2892. http://dx.doi.org/10.1016/j.ijhydene.2009.01.072

[48] Ojani, R., Raoof, J.B. and Fathi, S. (2009) Poly(o-aminophenol) Film Prepared in the Presence of Sodium Dodecyl Sulfate: Application for Nickel Ion Dispersion and the Electrocatalytic Oxidation of Methanol and Ethylene Glycol. 
Electrochimica Acta, 54, 2190-2196. http://dx.doi.org/10.1016/j.electacta.2008.10.023

[49] Shaidarova, L.G. and Budnikov, G.K. (2008) Chemically Modified Electrodes Based on Noble Metals, Polymer Films, or Their Composites in Organic Voltammetry. Analytical Chemistry, 63, 922-942. http://dx.doi.org/10.1134/S106193480810002X

[50] Prasad, K.R. and Munichandraiah, N. (2002) Electrooxidation of Methanol on Polyaniline without Dispersed Catalyst Particles. Journal of Power Sources, 103, 300-304. http://dx.doi.org/10.1016/S0378-7753(01)00841-2

[51] Dnong, S., Xie, Y. and Cheng, G. (1992) Cyclic Voltammetric and Spectroelectrochemical Studies of Copper in Alkaline Solution. Electrochimica Acta, 37, 17-22. http://dx.doi.org/10.1016/0013-4686(92)80005-7

[52] Castro Luna, A.M. (2000) A Novel Electrocatalytic Polyaniline Electrode for Methanol Oxidation. Journal of Applied Electrochemistry, 30, 1137-1142. http://dx.doi.org/10.1023/A:1004050922065

[53] Ficicioglu, F. and Kadirgan, F. (1998) Electrooxidation of Ethylene Glycol on a Platinum Doped Polyaniline Electrode. Journal of Electroanalytical Chemistry, 451, 95-99. http://dx.doi.org/10.1016/s0022-0728(98)00086-2

[54] Nagashree, K.L. and Ahmed, M.F. (2010) Electrocatalytic Oxidation of Methanol on Ni Modified Polyaniline Electrode in Alkaline Medium. Journal of Solid State Electrochemistry, 14, 2307-2320. http://dx.doi.org/10.1007/s10008-010-1063-3

[55] Marioli, J.M. and Kuwana, T. (1992) Electrochemical Characterization of Carbohydrate Oxidation At Copper Electrodes. Electrochimica Acta, 37, 1187-1197. http://dx.doi.org/10.1016/0013-4686(92)85055-P

[56] Torto, N., Ruzgas, T. and Gorton, L. (1999) Electrochemical Oxidation of Mono- and Disaccharides at Fresh as Well as Oxidized Copper Electrodes in Alkaline Media. Journal of Electroanalytical Chemistry, 464, 252-258. http://dx.doi.org/10.1016/s0022-0728(99)00041-8 